\title{
GIVING REWARD HAVE GREAT IMPACT ON JOB SATISFACTION AND TEACHER COMMITMENT AT SMA SATYA DHARMA BALUNG JEMBER
}

\author{
Iit Maulidah ${ }^{1}$ \\ Imam Suroso $^{2}$ \\ Zainollah $^{3}$ \\ Higher Education of Economic Mandala \\ Email: iitmaulidah82@gmail.com
}

\begin{abstract}
The title of this research article is "giving reward has great impact on job satisfaction and teacher commitment at SMA Satya Dharma Balung Jember". This study aims to analyze and examine the effect of intrinsic rewards and extrinsic rewards on job satisfaction and teacher commitment in SMA Satya Dharma Balung Jember. This research includes causal, quantitative research, because this study intends to explain causal relationships (causality) between variables through hypothesis testing that has been formulated. The research population is all high school teachers of Satya Dharma Balung Jember. The sampling technique used is Proportional Stratified Random Sampling. The hypothesis proposed in this study is that there is a direct, positive, and significant influence of intrinsic rewards, and extrinsic rewards to job satisfaction and teachers commitment of SMA Satya Dharma Balung Jember. The test validity of research instrument used construct validity. Reliability test was done with Cronbach Alpha. The method of analysis used is path analysis and the calculation process is approached with multiple linear regression analysis. The results showed that intrinsic rewards and extrinsic rewards had a direct, positive, and significant impact on the teacher's job satisfaction of Satya Dharma Balung Jember high school. Intrinsic rewards, and extrinsic rewards had a direct, positive, and significant impact on the work commitment of SMA Satya Dharma Balung Jember teachers. Intrinsic rewards and extrinsic rewards had an indirect, positive, and significant impact on teacher commitment, through job satisfaction. Based on the findings of this study, it is expected that the award received in accordance with what is perceived, so that it appears on job satisfaction and ultimately lead to work commitments.
\end{abstract}

Keywords: Reward, Job Satisfaction and Commitment

\section{INTRODUCTION}

This research discussed about reward, satisfaction and commitment as Dessler (2000) in Nursanti (2001: 2-3) stated that "Reward is any form of payment or remuneration that a person provides for the work done." Mottaz and Pott (1986) in Akroyd et al. (2002: 3) also states about reward " extrinsic reward measurements with supervisory variables, co-workers, working conditions, salary and promotional 
opportunities whereas intrinsic rewards use variable involvement in tasks, task economics and task significance." Whereas Organ and Hamner (1982: 287) state about job satisfaction that: "Job satisfaction is one's attitude toward the job, like the other. It shows a complex set of consciousness (trust and knowledge), emotions (feelings, sentiments, evaluations), and behavioral trends. A person with a high level of job satisfaction has a positive attitude to work, and conversely a person who is not satisfied with his work has a negative attitude on his job. " The organizational commitment is the attitude that individuals have with the values and objectives to be achieved organization, so that individuals want to always maintain membership in the organization, and always want to give the best contribution for the organization.

In 1977 stands a formal education institution called SMA Satya Dharma located in Balung Jember district. Starting from the number of 15 students increased to 432 students. This means that SMA Satya Dharma is experiencing growth and bloom, both quantitatively, from the number of students, the number of buildings, educators and educational staff, and it becomes one of the high school regarded in Balung district. Growth and development of educational institutions are attracting attention so that the research conducted by the author. Finally it comes on a question: "Are there any factors that affect the growth and development of the institution?. What factors affecting the growth and development? Are teachers or educators find satisfaction or feel satisfied working in the institution?. Is it true that the factors of job satisfaction and teacher commitment to the institution become one of the factors that influence the growth and development of the institution?. Is giving reward is one factor that has a big impact on job satisfaction and commitment of teachers in SMA Satya Dharma Balung?.

This study was conducted to test whether intrinsic reward has a significant effect on teacher's job satisfaction, test whether extrinsic reward has significant effect on teacher's job satisfaction, test whether intrinsic reward has significant effect to teacher commitment, test whether extrinsic reward significantly influence teacher commitment and test whether job satisfaction has a significant effect on teacher commitment in SMA Satya Dharma Balung Jember.

\section{RESEARCH METHODS}

This research was conducted at SMA Satya Dharma Balung Jember, Jln. Puger in front of post office Balung. This research was conducted for 2 months in SMA Satya Dharma Balung, conducted from January to February 2017. The research population is all teachers in SMA Satya Dharma Balung Jember in class III, and IV in SMA Satya Dharma Balung Jember, as many as 43 teachers. The sample are all teachers of Satya Dharma Balung. In this study the sample is the same as the population so it does not use sampling technique or use census.

The type of research is causality research that wants to achieve clarity in the form of cause-effect between several concepts or some variables or some strategy. The design of this research is explanatory research because its purpose is to explain causal relation between variables. Variables in this research are:

1. Independent variable are intrinsic reward (X1) and Extrinsic rewards (X2).

2. Dependent variable are Job satisfaction or (Y1), and Teacher commitment or (Y2).

For independent variables 1) Intrinsic rewards (X1), namely: rewards that are sourced from one's internal, 2) Extrinsic reward (X2), namely: rewards derived from sources outside of a person. The indicators used are: Mottaz 1981 in colbery; (2004: 72): 1) Working Conditions in General: is the degree to which there are resources to perform decent work consisting of physical facilities, equipment, work load and number of work; 2) Career development: is the opportunity of every 
employee to develop a career; 3) Increase of rank and position: is the attention of the institution or institution to the promotion and position of its employees; 4) Achievement of work: is the attention of agencies or institutions to give awards for employees who have job performance. The size of the indicators mentioned above is Likert Scale with a range of scores: $5=$ strongly agree; $\quad 4=$ agree; $3=$ doubtful; $2=$ disagree; 1 = Strongly disagree.

For dependent variable (Y) a) Job satisfaction: is a reflection of the gap between what is desired from work (valued valuable) and what is received from the job. The indicators used are: According to Pierce and Gardener (2002; 192): 1) Variation of skill that have can expedite the work; 2) The work undertaken is clearly planned; 3) Job involvement can improve performance; 4) Freedom in preparing work plan.

For commitment to the organization, it is the circumstance in which the individual becomes bound by his activities, and furthermore retains his activity and involvement. The indicators used are: 1) strong belief and acceptance of organizational goals and values; 2) the willingness to strive as part of the organization, 3) a strong desire to remain a member of the organization.

The size of the indicators mentioned above is Likert Scale with a range of scores: $5=$ strongly agree; 4 = agree; $3=$ doubtful; $2=$ disagree $; 1=$ Strongly disagree

This research used data collection method observation, interview and questionnaire. Hypothesis testing is done by path analysis. The calculation process is approximated by a standardized linear regression analysis that is standardized and processed with the SPSS 14.00. The real level used is $\alpha=0.05$ or $\mathrm{P} \leq 0.05$ raised in the code $(\operatorname{Sig} \mathrm{T})$ to test the direct effect of the independent variables on the dependent variable. To determine whether the Multiple Linear Regression model used for this analysis meets the classical assumptions that include:1) Normality Test; 2)
Multicolinearity Test; and 3) Heteroscedasticity Test

\section{RESULTS ANALYSIS}

Respondents in this research are all high school teachers of Satya Dharma Balung who have class of group starting from 1 (one) to group 4 (four). The total number of high school teachers of Satya Dharma Balung who have group rank from group 1 (one) to group 4 (four) year 2017 as many as 43 people, while the number of samples taken in this research is 43 people. The description of each respondent can be affirmed as follows:

Validity test in this research use construct validity, from the esult it can be stated that all the items of the extrinsic variable question at $\alpha=0.05$ are valid, so the overall score of these indicators can provide a good representation of the extrinsic variables. All of the items of job satisfaction variable at $\alpha=0.05$ are valid, so the overall score of these indicators can give a good representation on the variable of job satisfaction. It also for the employee commitment variable, questions at $\alpha=0.05$ are valid, so the overall score of these indicators can provide a good representation of the employee's commitment variable.

Reliability test in this research was done by Cronbach Alpha. The instrument is said to be reliable if it has a Cronbach Alpha value greater than 0.60 (Nunnaly, 1978: 39). That all variables studied at $\alpha=$ 0.05 are reliable (reliable), so the four research variables (X1, X2, Y1, and Y2) can be analyzed with multiple linear regression analysis.

Path analysis is done by standardize regression using SPSS software. The result of the analysis shows that the effect of reward extrinsic (X2), on job satisfaction (Y1) and extrinsic rewards to teacher commitment (Y2) is quite significant (with very little risk of fault, close to $p=0,000$ ), each with $\mathrm{p}$ value (Y1) with $\mathrm{p}=0,015$, influence of job satisfaction (Y1) to teacher 
commitment (Y2) with $\mathrm{p}=0,026$ and influence intrinsic reward (X1) to job satisfaction (Y1) with $\mathrm{P}=0.050$.

Extrinsic reward (X2) has a dominant influence on job satisfaction (Y1) with direct path coefficient of 0.660 or path from extrinsic reward (X2) to job satisfaction (Y1) is a stronger influential path, followed by path from extrinsic (X2) to Commitment of teacher (Y2) with direct path coefficient of 0,513, Intrinsic reward (X1) to job satisfaction (Y1) with direct path coefficient of 0,301 , job satisfaction (Y1) to teacher commitment (Y2) with direct path coefficient coefficient 0,282 , and intrinsic reward (X1) to teacher commitment (Y2) with direct path coefficient of 0,198 .

The indirect effect test is done by looking at the test result of the paths passed, if all the paths are significant then the indirect effect is also significant, and if there is at least one significant nonsignificant path, the indirect effect is said to be non significant.

Path analysis in the form of equation is presented as follows:

$$
\mathrm{Z} \text { job satisfaction }=0.301 \mathrm{Z}
$$

Reward Instrinsik $+0.660 Z$ Reward Extrinsic

$\mathrm{Z}$ teacher commitment $=0,198 \mathrm{Z}$

Reward Instrinsik $+0,613 \mathrm{Z}$ Reward Extrinsic +

\subsection{Z Job Satisfaction}

Testing Model Validity

A. Coefficient of Total Determination $\left(\mathrm{R}_{\mathrm{m}}{ }_{\mathrm{m}}\right)$ The total data diversity that can be explained by the model is measured using the formula:

$$
\begin{aligned}
& \mathrm{R}^{2}{ }_{\mathrm{m}}=1-(\mathrm{Pe} 1) 2(\mathrm{Pe} 2) 2 \\
& \mathrm{P}_{\mathrm{ei}}=(1-\mathrm{R} 2 \mathrm{i}) \\
& \mathrm{R}^{2}{ }_{\mathrm{m}}=\text { Coefficient of Determination }
\end{aligned}
$$

(R2 ) = Interpretation of $\mathrm{R} 2 \mathrm{~m}$ equals interpretation of Coefficient of Determination (R2) on regression analysis. therefore:

$$
\begin{aligned}
\mathrm{R}_{\mathrm{m}}^{2} & =1-\left(\mathrm{P}_{\mathrm{e} 1}\right)^{2}\left(\mathrm{P}_{\mathrm{e} 2}\right)^{2} \\
& =1-(1-0,871)(1-0,924) \\
& =0.9919
\end{aligned}
$$

Meaning that the diversity of data that can be explained by the model is 0.9919 , or in other words the information contained in the data $99.19 \%$ can be explained by the model, while $0.81 \%$ is explained by another variable (which is not yet contained in Model) and the model in this study there is no path that is not significant so that the path diagram form if using triming theory.

\section{INTERPRETATION}

Based on the result of the coefficient of path test of direct influence of reward intrinsic to job satisfaction is 0,301 with $p=$ 0,01 meaning every effort of SMA Satya Dharma Balung increase intrinsic reward for employee through: increasing of satisfaction when variation of skill possess can expedite job, clearly planned, increased satisfaction when engaged in work so as to improve organizational performance, and increased satisfaction with the freedom in preparing a work plan can increase job satisfaction. The test results concluded that hypothesis 1 states that intrinsic rewards have a significant effect on job satisfaction in SMA Satya Dharma Balung is proven or supported by fact

Based on the result of coefficient test of path of direct effect of reward extrinsic to job satisfaction is equal to 0,660 with $p=$ 0.000 . This means that every effort of SMA Satya Dharma Balung increases extrinsic reward for employees through: improvement of physical condition (cleanliness and layout, lighting, air circulation, improvement of teacher opportunity to develop career, always pay attention to promotion and position of each teacher, and improvement in giving rewards for teachers who have job performance can improve job satisfaction. The test results concluded that Hypothesis 2 which states that extrinsic rewards have a significant effect on job satisfaction in SMA Satya Dharma Balung is proven or supported by fact.

Based on the result of the coefficient test of the direct influence of the intrinsic reward on employee commitment (Table 4.13 ), it is 0.198 with $p=0.050$. This means 
that every effort of SMA Satya Dharma Balung increases intrinsic rewards for employees through: increased satisfaction when variations of skills possessed to expedite the work, increased satisfaction when clearly planned work, increased satisfaction when engaged in work so as to improve organizational performance, and increased satisfaction With the freedom in working out the work plan can increase the commitment of teachers of respondents. In addition, the result of testing the effect of indirect coefficient indicates that the indirect influence of intrinsic reward on teacher commitment through job satisfaction is significant and positive. The test results conclude that hypothesis 3 which states that the reward intrinsic significant effect on work commitment in SMA Satya Dharma Balung is proven or supported by facts.

The result of path coefficient test of direct effect of extrinsic reward on work commitment, is 0,513 with $p=0,000$. This means that every effort of SMA Satya Dharma Balung improves extrinsic reward for teachers through improvement of physical condition (cleanliness and layout, lighting, air circulation), improvement of teacher opportunity to develop career, always pay attention to promotion and position of each teacher, and improvement in Rewarding things for teachers with work performance can improve teacher commitment. The result of indirect coefficient test shows that the indirect effect of extrinsic reward on teacher commitment through job satisfaction is significant and positive. Based on the results of these tests it can be concluded that the hypothesis 4 which states that the reward intrinsic significant effect on teacher commitment in SMA Satya Dharma Balung is proven or supported by facts.

Based on result of coefficient test of direct influence of job satisfaction toward teacher commitment, is equal to 0,282 with $p=0,026$. This means that every effort of SMA Satya Dharma Balung improves job satisfaction of teachers through: improving skill variation, clearly planned job, increasing the inconvenience of a workgroup to a job, and the freedom of freedom in preparing the plan to increase teacher commitment. The test results conclude that Hypothesis 5 which states that job satisfaction has a significant effect on teacher commitment in SMA Satya Dharma Balung is proven or supported by facts.

\section{CONCLUSION}

Based on the discussion above it can be conclude that intrinsic and extrinsic rewards have a direct, positive, and significant impact on job satisfaction and work commitment in SMA Satya Dharma Balung. Job satisfaction also has a direct, positive, and significant impact on work commitment in SMA Satya Dharma Balung. All the variables have a direct, positive and significant impact on job satisfaction and work commitment in SMA Satya Dharma Balung.

\section{SUGGESTIONS}

The results of this research can be used by SMA Satya Dharma Balung to give more priority to increase intrinsic and extrinsic rewards through increasing job satisfaction. Expected rewards received in accordance with what is perceived, then the positive attitude of teachers will appear in job satisfaction. While the job satisfaction of teachers means has fulfilled all his expectations in the organization. Thus the teacher considers that work is a very important part. Therefore, the teacher views the organization as an object that must be placed as an important part of his life, thus creating an organizational commitment from the teachers.

\section{REFERENCES}

Akrioyd, D., B. Richards, and T. O'Brien. 2002. The Predictive Value Selected Intrinsic and 
Extrinsic Rewards As Determinants of Health Occupations Teacher' Work Satisfaction: Journal of Health Occupation Education. 7. 2. 1-22. North Carolina.

Akrioyd, D., B. Richards, and T. O'Brien. 2002. The Predicting The organizational Commitment of Marketing Education and Health Occupations Teacher by Work Related Rewards: Journal Industrial Teacher Education. 32. 1. 1-14. North CarolinaAlbanes, Robert, and Fleet, David D. Van, 1983. Organization Behavior: Managerial View Point, New York: The Dryden Press cd.

Arikunto, Suharsimi. 2002. Prosedur Penelitian Suatu Pendekatan Praktek. Edisi Revisi ke-5. Jakarta: Rineka Cipta.

Cascio, Wayne F., 2003. Managing Human Resources Management Productivity: Quality of Work Life, Profit. New York: McGrawHill.

Gibson, Ivancevich, Dornely, 1992, Organisasi perilaku, Stuktur, Proses, Edisi ke - 5, cetakan ke 5, Erlangga, Jakarta.

Ivancevich, John M. 1987. Organizational Behavior and
Management. Texas: Business Publication, Inc.

Lawler III, Edward E., Susan Albers Mohrman and George Benson. 2001. Organizing for High Performance Empleyees Involment, TQM, Reenginering and Knowledge Management in The Fortune 100. The CEO Report San Francisco: JosseyBass.

Luthans, Fred. 1998. Organization Behavior. 8th Edition. North America: McGrawHill/ Irwin.

Martoyo, Susilo,1992 Manajemen Sumber Daya Manusia, Edisi Keempat, Penerbit BPFE, Yogyakarta.

Maslow,Abraham,1994,Motivasi dan Kependidikan 2,Penerbit PT Pustaka Binawan Presindo,Jakarta.

Robbins, Stephen P. 1996. Perilaku Organisasi: Konsep, Kontroversi, Aplikasi. Jilid 1 Terjemahan Handayana Pujaatmaka. Jakarta: PT Prehallindo.

Santoso, Singgih. 2000. Buku Latihan SPSS Statistik Parametrik. Cetakan ke-1. Jakarta: PT Elex Media Computindo.

Sugiono, D.R. 2003. Metode Penelitian Bisnis. Cetakan ke-5. Bandung: Alfabeta. 